\title{
コミュニケーション場のメカニズムデザインに向けた システム論の構築と展望*
}

谷口 忠大 ${ }^{\dagger}$

\author{
Towards System Theory of Communication-field \\ Mechanism Design*
}

Tadahiro TANIGUCHI ${ }^{\dagger}$

\begin{abstract}
People create collective intelligence and make decisions through discussion, conversation, dialogue and debate in organizations and communities in our daily life. This is an autonomous social behavior naturally performed by people as a multi-agent system. It is an important issue in the modern society how to control such a communication field, to optimize knowledge sharing, decision making and learning process in a group. In this paper, we device a research approach called communicationfield mechanism design by grasping the phenomena as a control problem of a human social system. In addition, we introduce some pre-existing communication-field mechanisms, such as Bibliobattle and Parliamentary Debate to clarify the notion of communication-field mechanism. We also clarify the relation with the proximity concept such as collective intelligence mechanism, gamification, and mechanism design.
\end{abstract}

\section{1.はじめに}

組織の中, 社会の中で, どのようにすればより生産的 な議論を行い,より論理的な討議を行い,より包摂的な 話し合いができるのだろうか。知識創造社会において， また, 情報化社会において,「知」の循環と拡張, 洗練と 創造はますます必要となっている [1]．人々は組織や社会 の中で，各自の頭の中に分散化され断片化された「知」 を有している，われわれは質の良い議論，討論，話し合 い, 対話といった言語的コミュニケーション（以降，ま とめて議論とよぶ）によりこの断片化された「知」から 集合知を生み出し, 組織や社会の中で活用していくこと ができる。しかし，人間集団という社会システムにおい て，議論により集合知を生みだすことは実際には難しく， 多くの組織や社会の中で参加者のもつ率直な想いや知識, 考え方を対話の場に引き出せない, 表出された情報や考 え方を論理的で公正な議論を通して集合知として統合で きない，もしくは，そもそもそのための努力がなされて

\section{* 原稿受付 2019 年 2 月 13 日}

†立命館大学 情報理工学部 College of Information Science and Engineering, Ritsumeikan University; 1-1-1 Nojihigashi, Kusatsu, Shiga 525-8577, JAPAN

Key Words: communication, social system, gamification, knowledge management, mechanism design, decentralized systems.
いないといった問題を抱えている. 企業や社会における 意思決定でも, 上意下達と過剩な忖度, 強い同調圧力, 「どんな意見か」より「誰の意見か」の重視，ファクトよ り印象・感情の重視などが横行し，これが社会や産業の 生産性を著しく毀損している。これをいかに合理的に問 題解決するかは，21 世紀において深化する知識創造社会 において，われわれの社会が真の発展を遂げるために重 要なシステム工学的課題である.

議論や話し合いといえば，言語的コミュニケーション であるからして「人文科学的な研究対象であり, 工学か らは遠い」という心象を持たれるかもしれない.しかし， 工学という研究態度は必ずしも対象系のみにより決定 されるものではない，工学とはより望ましい状態，まだ 存在していない状態，目指す成果を得るためにどのよう にすれば良いかを追求する学問である．言語的コミュニ ケーションを行い, 集団の構成員がもつ知識や思考を表 出させ，それを統合する，もしくは，それと避けがたく 発生する, 各構成員の認識の深化や, 言語および思考技 術の向上を同時に図るといったコミュニケーション場の 性能向上, 限界までの革新を目指して, 工学的研究を展 開しようというのがコミュニケーション場に関する工学 的研究として定義し得る.いかにコミュニケーション場 に所望の振舞いをさせ，所望の成果を生むために，どの ような人工物を設計し，どのように対象系を制御するか 
というのは工学的な問いとなり得る. その論理的帰結と して本論文で改めて概念構築するのが，システム論的ア プローチに基づくコミュニケーション場のメカニズムデ ザインなのである.

ここで，コミュニケーション場とは自律的な言語的コ ミュニケーション主体である個々人が何らかの集まり， 議論，討議，話し合いなどを行う場をよぶ，それは空間 的な場所のみならず，その状況を包み込む社会的なルー ルや，構成員に与えられた役割などを広く包含する概念 である。コミュニケーション場自体は，理念的な存在で はなく，むしろ，現場での現象としての言語的コミュニ ケーションが生じている場そのものを指す，本論文で問 題とするのは，このコミュニケーション場を制御し改善 するためにわれわれは何をどのように設計すべきか，ま た，その前段階としてそのシステム全体をどう捉えるべ きかということである.

本論文の構成は以下である。第 2 章でコミュニケー ション場をシステム論的立場から再解釈し，コミュニ ケーション場のメカニズムデザインの位置付けを明らか にする．第 3 章では既存のコミュニケーション場のメカ ニズムをいくつか取り上げ，その比較を行いつつ，メカ ニズムの設計変数という概念を導入する。第 4 章では 学問としてのコミュニケーション場のメカニズムデザイ ンに関する近接領域を紹介し，それらの学問とコミュニ ケーション場のメカニズムデザインの関係を論じる。第 5 章においてまとめる

\section{2. コミュニケーション場のメカニズムデ ザイン}

2.1 創発システムとしてのコミュニケーション場

自律分散システムが，そのシステムにおいて創発特性 を有するとき，そのシステムを創発システムとよぶ。言 語的，もしくは記号的コミュニケーションを行う人間の 集団は記号創発システムとして捉えられる $[2,3]$. 自律分 散システムとは複数の知的な行動主体が自らの意思決定 に基づいて行動することによって形成される系である。 本論文での立論はコミュニケーション場が自律分散シス テムであり，さらには創発システムであるというシステ ム論的な認識から始まる.

まず, コミュニケーション場では誰一人，他者の発言 や解釈といった行動を，直接制御することはできない. また，他者の知識や認識に直接アクセスして情報を得 ることはできない。われわれの社会において，個々人の 知識や認識は常にゲーム理論でいうところの私的情報 (private information)なのである。言語的コミュニケー ションにおける諸問題の多くは「他人の頭の中はのぞけ ない」という前提から生じる。 それは, 人間一人ひとり が自律的な存在であり，その認知が閉じている，という ことと等価である。コミュニケーション場の制御は，自 律分散システムの制御として，その設計は個々のエー
ジェント（議論への参加者）を直接制御するという視点 ではなく，制約条件やインセンティブ（誘引）を設計す ることで周縁制御，もしくは間接制御を行うという視点 へと移行するのが適切となる。

コミュニケーション場においては，ミクロレベルのコ ミュニケーション活動自体（つまり, 議論の内容や, そ の場での相互作用）が，そのコミュニケーション場の構 成員や，それにとどまらず母集団や組織のもつ共通信念 や制度を明に暗に変化させていく。この形成された秩序 は，コミュニケーション場における相互作用に制約を与 える，異なる上位の層，つまり，マクロレベルに形成さ れる秩序は制約条件として，ミクロレベルの相互作用に 影響を与えるのである1.コミュニケーション場にはミ クロマクロループが存在し，創発システムと見なせる. そのために，これを前提とした工学的アプローチが重要 となるのである。

\section{2 コミュニケーション場のシステム階層性と 設計対象}

コミュニケーション場の改善を目指す場合に「何を設計 対象, 工学的研究対象とすべきであるか?」という問いに 対する答えは，コミュニケーション場が創発システムであ るという理解と, コミュニケーション場が潜在的にもつ設 計の階層性から自ずと導出される. Fig. 1 にコミュニケー ション場の設計の階層性を表す図を示す。下から順に， コミュニケーションの軌跡 (Trajectory of communication), コミュニケーション場 (Communication field), コ ミュニケーション場のメカニズム (Communication-field mechanism), コミュニケーション場のメカニズムデザイ ンの設計原理 (Design principle of communication-field mechanism) である.

コミュニケーションの軌跡とは実際のコミュニケーショ ン場での発話内容や人々の振舞い, 時間の使われ方, 参 加者の内部状態変化など, コミュニケーション場におい て発現した事象そのものである。このうち，会議のそれ ぞれの発言そのものなど観測可能なものを観測されたコ ミュニケーションとよぶことにする。 コミュニケーショ ン場が自律分散システムであることを考えると，この層 を直接制御することは不可能であり，また，会議が各参 加者の発言を通して私的情報の表出を目的の一つとす るために，外部の制御器によってこの振舞いに介入する ことはそもそも無意味である，たとえば，政治家の夕ウ ンミーティングにおいて，質疑応答が事前に準備されて 換骨奪胎されることが問題となることがあるが，それは この観測されたコミュニケーションの層でコミュニケー ション場を設計・制御しようとしたことが疑問視された

\footnotetext{
1とえば，とくにルールも役割を定めずに，フリーディ スカッションを行うと, 自然と（ほぼ不可避に）司会 的な役割を演じる人が生まれるということもこの一つ の現れである，役割分担の秩序の創発である。
} 


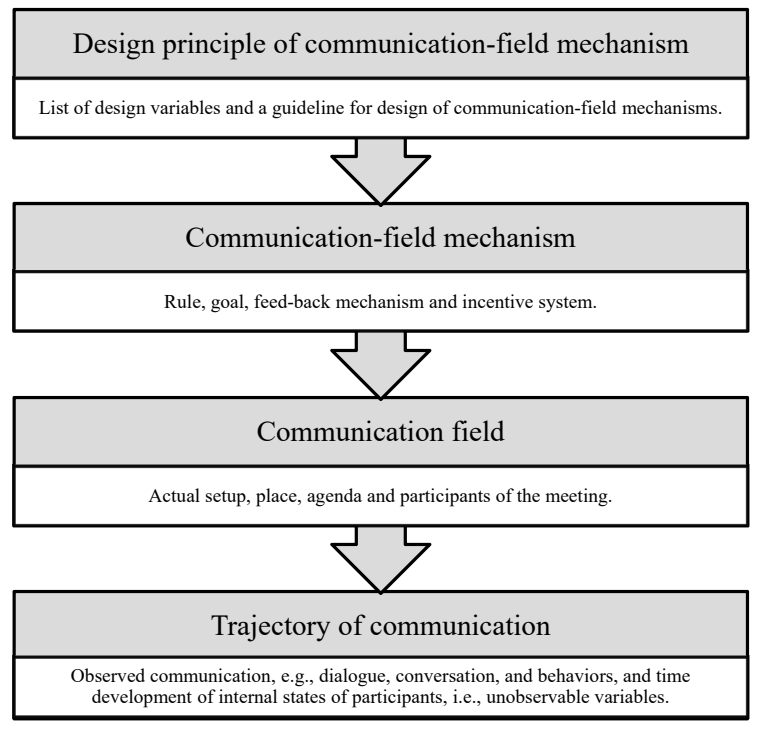

Fig. 1 Design hierarchy of communication field

のだ

コミュニケーション場とはコミュニケーションが行わ れる場であり，その空間的なデザインや，議題の設定， 小道具の準備や，司会進行の進め方などを含めた概念 である、「コミュニケーション場の設計」を行うという 場合には，通常，コミュニケーションが始まる前に空間 デザインや，事前準備などを指す。たとえば，ファシリ テータの選出や, 議題の設定, 会議参加者の選別という ことまでもがコミュニケーション場の設計に属する。コ ミュニケーション場の制御といった場合には, ファシリ テータが議題を誘導したり, 状況に応じて発言権をより 多く話させたい人に動的に配分したりするようなことを 指す。コミュニケーション場の設計も制御も，観測され たコミュニケーションに対しての直接的な制御に比べる と間接的ではあり，自律分散システムとしてのコミュニ ケーション場の前提には反していないが，いくつかの問 題をはらむ.

まず，コミュニケーション場の設計に関しては，コミュ ニケーション場そのものが一回限りのものであり, この ような場ではどのような設計をすべきであるという知見 が再利用しにくいという点である。 また, 議題や参加者 などは会議の主題や機会ごとに外部から与えられるもの であり，設計変数として扱うには難がある．また，ファ シリテータを導入して, 適切な会議運びをすれば生産的 な議論が期待できるものの，それはファシリテータの技 能に依存した職人芸であり，そのような問題解決では， スケーラブルに国内外津々浦々のコミュニケーション場 の生産性を高めることはできない. さらに，議論には数 名の小規模のものから，百人規模の大規模なものまであ るが，小規模なものにおいて有能なファシリテータの存 在を期待することはできない.コミュニケーション場の
設計や制御は，空間デザインや一回一回の対話の記録な ど，目に見える現象としてその様子や取り組みを可視化 しやすく，まちづくりや社内改革の事例や報告書などで 注目を集めることがあるが, 成功事例集として事例が蓄 積されるに留まってしまいがちである。それは，一回性 のあるコミュニケーション場の「場」自体を設計・制御 対象としていることからの自然な帰結であると考えられ る。文献 $[4,5]$ において,「空間」の設計, ファシリテー ションとして言及される従来のコミュニケーション場へ のアプローチは, このコミュニケーション場の設計・制 御に対応する.

一方で，コミュニケーション場にはそれを支配する制 度や制約が明に暗に存在する。例として，議長がおり， 発言者は挙手して発言するタイプの進行を行う会議で は，この進行のルールがすでにメカニズムの一つとなっ ている，あるメカニズムが明に暗に設定されると，そこ から各参加者にとってのインセンティブや制約が生じる. たとえば大人数で行われる上記会議では発言が抑制され る傾向や，本音が出にくいという現象が生じやすい.こ れは，一度に発話できるのが一名であるために，発言す ること自体が非常に大きな意味をもってしまうこと（組 織内での立場に影響を与える）や，そもそも，全員が議 論を戦わすと収集がつかなくなるので自然と自律分散的 に各参加者が抑制をかけることなどによる，また，指名 には議長に権限があり, 一定の会議運営における権力行 使が可能である。このような会議運営手法, もしくは, メカニズムは, 組織による議事の承認や意思決定には向 いているが，皆から広く意見を募ることを目的としたコ ミュニケーション場には向いていない 1 . 一方で, この ような運営を行うとかなり再現性が高く, 同じような沈 黙が生じるという事実は注目に值する。それは観測され るコミュニケーション，つまり，具体的な発言や結論と いう意味での再現性ではなく，観測されるコミュニケー ションにおいて生じるある種のパターンの性質という点 での構造的な再現性である。

コミュニケーション場の個別性を超えて, 多様なコミュ ニケーション場に適用可能であり，議論に支配的な影響 を与えることのできるルールの集合をコミュニケーショ ン場のメカニズムとよぶ. コミュニケーション場が創発 システムであることを受け入れると，コミュニケーショ ン場のメカニズムが, 工学的設計対象, 研究対象として 妥当な粒度をもつのである。

コミュニケーション場のメカニズムとして捉えられる 事例はすでに多く存在する。しかし，それらを蒐集する のみでは，工学にはなりえない。 その新たな設計, 改善, また，それらの性質を明らかにすることで，より効果的 な適用法を見いだすことが工学である。つまり，コミュ

\footnotetext{
1このような会議の場をうまく運営する手法としてロ バート議事法などが知られている。
} 
ニケーション場のメカニズムデザイン論の構築が，バラ バラなコミュニケーション場に関する設計・制御の議論 を結束させる，学術的な扇の要を生む。 その最終到達点 として考えられるのがコミュニケーション場のメカニズ ムデザインの設計原理の抽出であろう。設計原理とは個 別メカニズムを設計するうえでの一般理論である。

\section{3 コミュニケーション場のメカニズムとシス テムダイナミクス}

システム論的な俯瞰から, 改めてコミュニケーション 場のメカニズムを論じる．文献 [4]ではコミュニケーショ ン場のメカニズムデザインを

参加者が自らの効用を最大化するように行 動する結果，実りあるコミュニケーションがな されることによって目的がみたされるメカニズ ムを構築するという問題をたて，これに対する 設計解を提案すること

として定義している ${ }^{1}$ 。これは経済学における合理的意 思決定主体を仮定して市場を見，制度を見，その制度設 計の質を論じる視座に即したものである。ミクロ経済学 やゲーム理論は，自律分散システムとしての人間集団の 個体ごとの行動と，その集団としての帰結を，各行動主 体の自律的意思決定に基づいて論じる学問である。経済 学がおもに問題とするのは経済行動であるが，言語的コ ミュニケーション行動を主たる対象とするコミュニケー ション場のメカニズムデザインが，そのような学問と同 型的な認識枠組みをもつのは妥当であろう.

コミュニケーション場のメカニズムを設計するとなっ たときに，その範囲に含まれる要素にはどのようなも

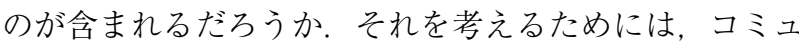
ニケーション場自体を一つの動的なシステムとして見な す必要がある。Fig. 2 に一つの記述的モデルを示す。こ の記述的モデルが本論文の新規性の一つであり，コミュ ニケーション場を自律分散システムと見なし，その周縁 制御を行うための制約条件やインセンティブ，フィード バックの設計を問題として工学的設計問題と見なすシス テム描像を提供する。

コミュニケーション場というのは，一つのプラントの ようなものである。 そこには入力される要素と, プラン 卜に相当するコミュニケーション場，そして出力される 要素が存在する。

入力の中で最も重要な資源は参加者である。システム 制御論の見立てにならって，仮に $i$ 番目の参加者の状態 変数を $\left\{X_{i}\right\}$ とおこう，その要素としては，少なくとも， 参加者の議論に関わるスキル $\left\{S_{i}\right\}$, 議題に関わる知識

1引用文献では「コミュニケーションのメカニズムデサ イン」という語を用いているが，論じているのは個別 コミュニケーション場で用いられるメカニズムについ てであり，以降,「コミュニケーション場のメカニズム デザイン」という言葉が用いられるようになった。本 論文でも後の用法に従う。

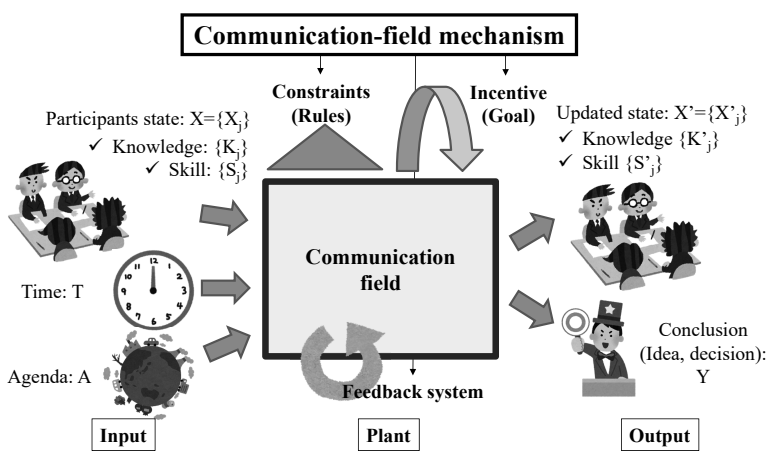

Fig. 2 Overview of communication-field as a plant processing distributed knowledge, and communication-field mechanism controlling the field indirectly

$\left\{K_{i}\right\}$ といったものが考えられる. 知識には, 大きく分 けて個々人の願望に関する知識と事象に関する知識があ る [5]. 客観的な知識ではなく, 組織の構成員たる参加者 一人ひとりが何を望んでいるかという主観的な知識もま た組織の意思決定には重要である。これに加えて，時間 $T$ や, 議題 $A$ といったものがコミュニケーション場へと 投入される ${ }^{2}$.

コミュニケーションの軌跡（つまり，各参加者のコミュ ニケーション行動の時間発展) は, 制約条件やインセン ティブ，フィードバックに影響を受ける。これらがコミュ ニケーション場のメカニズムの主たる構成要素である。 コミュニケーション場のメカニズムはある意味でコミュ ニケーションをゲームとして捉えたときのルールとも捉 えられる。マクゴニガルはゲームの四要素としてゴー ル，ルール，フィードバック，自発的な参加を挙げてい る $^{3}[6]$.これらにより構成されるメカニズムが，参加者 の状態変数 $\left\{X_{i}\right\}$ 間の相互作用や発言内容, 時間発展に 影響を与える。この間，各参加者のコミュニケーション 行動は，発言するにしろ，黙り达むにしろ，それらは自 らの利得最大化行動（もしくは満足化行動）の帰結とし て得られると捉える.

結果的に, 時間が尽きる, 全員が話し終わる, 議題が 尽きる，などの終了条件が満たされれば議論は終わるわ けであるが，その出力は大きく分けて二種類存在し，コ ミュニケーション場の意義は，双方の視点から評価され る。一つ目は議論のうえで得られた結果，つまり，議決 された議案や，出されたアイデアなどの形式知としての 成果 $Y$ である。集合知や集団的意思決定の議論では，こ の出力に主たる焦点があてられてきた。その重要性は色

2これらは現時点では記述的なモデルとして仮置きする に留めるものであり，十分性や，その計測・推論可能 性などについては現時点で主張するものでない.

こここでのゲームとはゲーム理論の意味でのゲームで はなくて，テレビゲームやスポーツといった意味での ゲームである。 
あせないものの，もう一つの出力は各参加者の内面に扔 ける変化である。コミュニケーション場での相互作用を 終えたときに，その場に投入されていた参加者の状態変 数は $\left\{X_{i}^{\prime}\right\}$ へと変化する. 知識やスキルも $\left\{K_{i}^{\prime}\right\},\left\{S_{i}^{\prime}\right\}$ へ と変化するであろう。実際の組織や世の中に扔いては, 議論に扔いて重要なのは出された結論のみならず，共有 された知識や認識，または，その議論自体を通して高め られる個々人の議論のスキルである場合がある，業種な どにもよるが，多くの話し合いにおいては，むしろ，後 者の方が実際には支配的であることも多い。コミュニ ケーション場のメカニズムデザインは，世の中における より多くのコミュニケーション場の生産性を高めること を目指すので, 前者のみならず後者も重要な研究対象, および，コミュニケーション場のメカニズムを設計する ときに最大化すべき評価指標となる。

本節で導入したコミュニケーション場の記述的モデル は極めて一般性の高いものであり, $\left\{X_{i}\right\},\left\{K_{i}\right\},\left\{S_{i}\right\}, Y$ といった変数の設定に関してもコミュニケーション場の メカニズムデザインに関する議論を進めるうえでは十分 な表現力をもっていると考えている。あらゆる記述的モ デルと同様に本モデルは暫定的なものではあるが，暫定 的なものであったとしても，当面はこれらの変数群や制 約条件，インセンティブ，フィードバックといった要素 に関連付けてさまざまなメカニズムを分類し，整理し， 解釈し, 議論を進めていくことが当該分野の発展のため には重要であろう.

\section{3.メカニズム事例と設計変数}

本章では具体事例として，ビブリオバトル，パーラメ ンタリーディベート，発話権取引，「件の宣言」を取り上 げたうえで，設計原理に至る道として，その類似と差異 を議論するうえでの設計変数の考え方を導入する.

\section{1 ビブリオバトル}

ビブリオバトルは文献 [7] に抏いて提案され，全国に 広がり，海外にも広まりつつあるコミュニケーション場 のメカニズムである. Algorithm 1 にビブリオバトルの メカニズムを示す ${ }^{1}$.「人を通して本を知る，本を通して 人を知る」のキャッチフレーズで知られ，書籍に関する 情報共有と，それぞれの参加者の人物や趣味，嗜好，知 識といった私的情報をコミュニティに扔いて共有する機 能を有する，近年では，読書教育や言語力向上といった 教育的な視点からも注目されており，文部科学省の第四 次「子供の読書活動の推進に関する基本的な計画」2 に

\footnotetext{
${ }^{1}$ ビブリオバトルには公式ルール (http://www. bibliobattle.jp/koushiki-ruru) が存在している が，本論文では可能な限り公式ルールの記述を踏まえ たうえで，疑似コードとして掲載する。

2 文部科学省 第四次「子供の読書活動の推進に関す る基本的な計画」http://www.mext.go.jp/b_menu/ houdou/30/04/1403863.htm
}

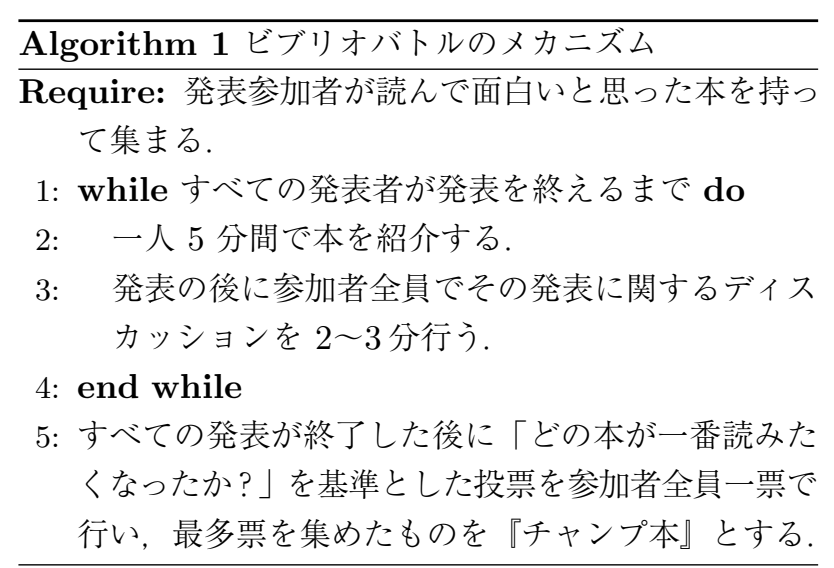

おいても推進していく重要性が主張されている.

ビブリオバトルは提案時から明確に, 参加者をマルチ エージェントシステムとして見なして，そのシステムか ら本に関する知識を表出させるためのメカニズムとして 設計されている，奥らはこうして成立するビブリオバト ルの推薦システムとしての性質を他の推薦システムとの 比較によって検証している [8]. ビブリオバトルには多 様な機能があるが詳細は文献 [9] を参照いただきたい.

\section{2 パーラメンタリーディベート}

ディベートの歴史は古く, 議会制民主主義発祥の地で あるイギリスにおいて，その議会の議論を模倣してゲー ム化されたのがパーラメンタリーディベートである。そ のルールには一定の枠はあるものの，子細に入ればさま ざまなバリエーションが存在する，本論文では一般社団 法人パーラメンタリーディベート人財育成協会 ${ }^{3}$ が標準 化している即興型ディベートを取り上げて説明する [10]. パーラメンタリーディベートのメカニズムを Algorithm 2 に示す. パーラメンタリーディベートは, 誰か が設計したというよりは，歴史的に，文化的に形成され てきた類のコミュニケーション場のメカニズムの好例で あろう。興味深い点は, このメカニズムの目的は結論を 出すことではなく，論理的な議論をするトレーニングに あるという点である。 二項対立としての賛成反対を人工 的に作るのも，論理的な二項対立をコミュニケーション 場のメカニズムに映し出したものと捉えることができる また, 賛成反対の立場をランダムに決定することも, 議 論において意見を出すことによって，人格攻撃が発生し たり，本当の人格に紐付いた考えを出すことで人間関係 に影響が出てしまうことを，事前に抑止する装置になっ ている。パーラメンタリーディベートのより詳細な説明 に関しては文献 $[10,11]$ などを参照いただきたい.

\section{3 発話権取引}

とくにメカニズムを設定しない話し合いにおいては， 年長者や立場の強いものが過剩に発話時間を使うことで, 発話の不均衡が生じる傾向にある。会議や話し合いにお

\footnotetext{
3 一般社団法人パーラメンタリーディベート人財育成協 会 http://www.pdpda.org/
} 
Algorithm 2 パーラメンタリーディベートのメカニ

ズム

Require: 主催者が論題を設定する.

Require: 参加者を 3 名ずつの 2 グループに分ける.

Require: 政府側（肯定側），野党側（否定側）を参加 者の意見とは独立にランダムに決定する。

1：政府側が 3 分間で定義を行い，肯定する理由 1 を述 ベる.

2: 野党側が 3 分間で肯定する理由 1 に反論し, 否定す る理由 1 を述べる。

3: 政府側が 3 分間で否定する理由 1 へ反論, 肯定する 理由 1 の再構築, 肯定する理由 2 を述べる.

4: 野党側が 3 分間で肯定する理由 1,2 に反論し, 否定 する理由 1 の再構築，否定する理由を述べる。

5: 野党側が 2 分間で, 野党側が勝っている理由をまと める。

6：政府側が 2 分間で否定する理由 2 へ反論し，政府側 が勝っている理由をまとめる.

7: ジャッジが内容と表現の二つの観点から総合的に判 断し勝敗を決める

いて発言時間が偏ることは一般的に望ましくないことと されている [12]. コミュニケーション場のメカニズムに よってこの問題を解決しようと提案されたのが発話権取 引である [13]. 発話権取引のメカニズムを Algorithm 3 に示す.

発話権取引を導入することで，発言時間が均等化され るように補正されるのみならず，話し合いの中から司会 者の役割をする者が消え，内容が自分の意見や理由を表 明するものである発言の割合が増加することが示されて いる [13]. 他のコミュニケーション場のメカニズムと比 較した際に，発話権取引の特徵的なのは，発話時間とい う資源を参加者内で分散的に資源配分するメカニズムと なっている点である．同様のメカニズムをWEB 会議へ と適用した場合でもほぼ同様の効果が得られることが 確認されている [14]. Fig. 3 は発話権取引のモバイルア プリケーションを用いて発話権取引を行っているワーク ショップの様子である

\section{4 「件の宣言」}

直接民主制による意思決定を体験する演劇ワークショッ プとして開発されたのが「件の宣言」1である [15]. 参 加者は与えられた方針を，本人のもともと持っている価 值観とは関係なく演じて, 議論して, 主張する。 その後, 演じることをやめ, 一個人に戻って, 無記名投票により そのコミュニティにおける「宣言」を採択するというも のである.このメカニズムを Algorithm 4 に示す.

ディベートと概観はよく似ているが, 反駁をするフェー ズはなく，また，四極という多極を取る点が特徵的であ

1件の宣言 http://eisei.info/xmmd/kudan.html
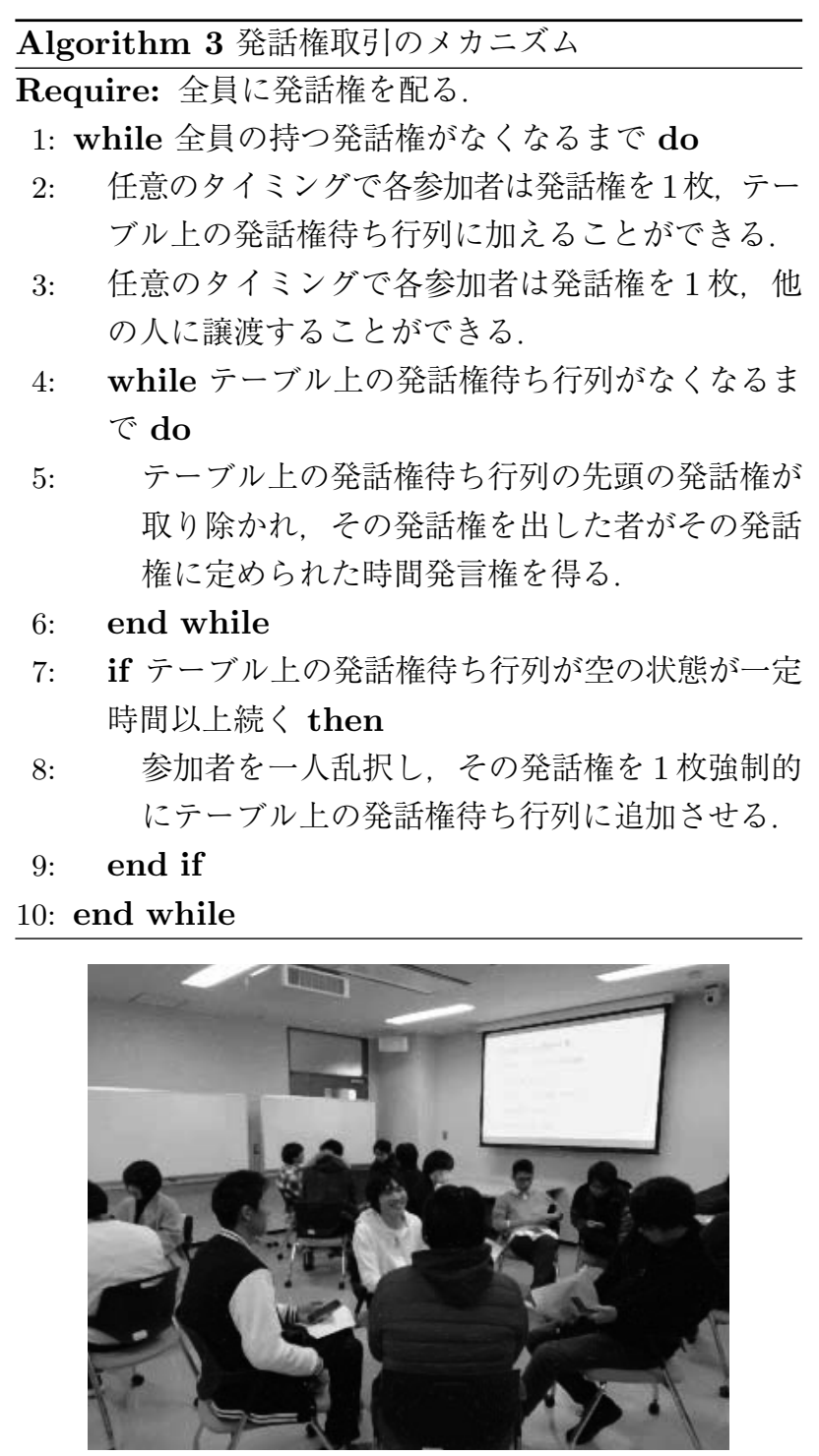

Fig. 3 Scene of workshop using Dealing Rights to Speak ("Hatsuwaken Torihiki" in Japanese)

る [16]. ディベートとの設計の異なりに呼応するように， その目的も異なる.「件の宣言」の目的は直接民主制によ る意思決定の体験（学習）であり，ディベートのような 論理的な議論のスキル習得ではない. また，ディベート では背景化している「演じる」という側面を前に出して いる点も特徴的である ${ }^{2}$.「件の宣言」は演劇ワークショッ プの一種であるが,「演じる」つまり演劇はコミュニケー ションにおける表現と密接に繋がっており, これをコミュ ニケーション場のメカニズムデザインにおいてどのよう に考慮に加えるかも重要な論点である.

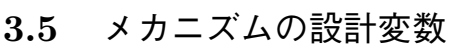

本章で例に上げたメカニズム以外にも，ブレインス トーミングやオープンスペーステクノロジーをはじめ, これまでファシリテーション技法や, 場作りの手法, ワー

2ただし，あまり意識はされないが，形式上はディベー トでも内閣総理大臣や野党代表を演じることになって おり, 演劇の要素は含まれている. 


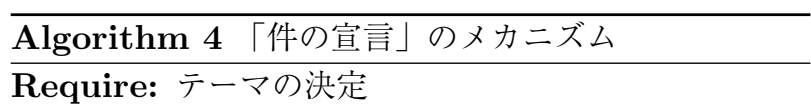
議論するテーマを決める。基本的には主催者があら かじめ決めておくが, 参加者の希望により決めても よい.

Require: チーム分け

参加者をランダムに，なるべく均等な人数になるよ うに 4 チームに分ける。 チームにはそれぞれ，参加 者本来の意見とは関係なく，過激 $\mathrm{A}$ 派，穏健 $\mathrm{A}$ 派， 穏健 $\mathrm{B}$ 派，過激 $\mathrm{B}$ 派の 4 派をランダムに割り当てる。

1: 演説準備のディスカッション

チームに分かれて議論し演説内容をまとめる（5～10 分間）。インターネット等で調べることは可とする.

2: 演説

チームとしての主張を演説する（各チーム 1 2 分 間）。演説の冒頭には必ず「賢明なるコミュニティ の諸君」というフレーズを入れる，演説では必ず全 員が発言をする。

3: ラウンドテーブル

全チームの演説終了後, 各チームのメンバーがなる ベく均等に混ざったグループを複数作り, 各グルー プでディスカッションを行う（5１0 分間）。なお， この時は自分の所属チームの立場としてディスカッ ションを行う。

4: 投票

ラウンドテーブル終了後, 4 チームは解散する。参 加者それぞれの心象によって，A／Bの二択で無記 名投票を行う.

5: 採択結果の宣言

開票し，最多票を得た意見をコミュニティの議決と し，議長が「本コミュニティでは○○が採択されま した」と宣言する.

クショップ運営手法, WEBサービスなどとよばれていた ものの中にも，コミュニケーション場のメカニズムと見 なせるものがさまざまに存在する，それらさまざまな手 法のコミュニケーション場のメカニズムとしての整理や 比較研究, 分析研究は今後の多くの研究者による研究論 文に委ねるが，本節では，コミュニケーション場のメカ ニズムの設計原理に向かう，大きな研究の文脈において 重要となる, メカニズムの設計変数の概念を導入したい.

従来のコミュニケーション場のメカニズムはそれぞれ がそれぞれの文脈において生まれ，また，設計され，更 新されてきたものである。しかし，コミュニケーション 場のメカニズムとよびうるもののすべては自律分散シ ステム（もしくは, 創発システム) としての, コミュニ ケーション場にルールを与え，インセンティブを与える ものである.よって，それらの間には比較により類似と 差異を見いだすことができる，四項目に関して，比較を 示したものを Table 1 にまとめる.
たとえば，ビブリオバトルを二人の発表者で行った場 合，それは「自分の紹介する本が面白いから読むべき だ!」と主張する政府側と,「対案としてこちらの本を読 むべきだ!」と主張する野党側によるパーラメンタリー ディベートに似てくる。しかし，そのように似せても， いくつかの差異が残る。 パーラメンタリーディベートに は主張のターンの後に, 反駁が存在する。一方で, ビブ リオバトルは他人のお薦めする本に対して反駁する機会 はない. ディスカッション時間においては, むしろ, 他 人の紹介本を否定するのではなく,「チャンプ本」を選ぶ 参考になるような情報を引き出すことが奨励されている. また，ビブリオバトルでは自分自身の意見，つまり，自 分自身のおすすめする本を読むべしと主張するが，パー ラメンタリーディベートでは，立場を乱択によって選ぶ. これら二つのコミュニケーション場のメカニズムは異な る効果を目指しており，結果として異なる設計にはなっ ている，しかし，逆の視点に立つと，異なる設計により， それぞれの機能を実現しているという見方もできる。つ まり，どのように対立構造の極配置をするのか， 反駁の 時間をどのように設定するのか，役割と人格をどのよう な手法で切り離すのかといったメカニズム設計上の変数 が存在する，これを，本論文ではメカニズムの設計変数 とよぶことにする.

コミュニケーション場のメカニズムの設計変数のリス 卜を明らかにすること自体は，コミュニケーション場の メカニズムデザインの研究の大きな目標である。それは, 生命科学において一時, ヒトのゲノムを明らかにするの が，その分野の大きな目標であったことに近い．本論文 ではその端緒として, メカニズムの設計変数という概念 を導入するに留める。一例として，本章で紹介した四つ のメカニズムを試みに三つの設計変数に関して比較した 表をTable1に示す.

たとえば，パーラメンタリーディベートにおいてその 極を四極化 (多極化) すると, 異なるコミュニケーション 場のメカニズムを作ることができる，そこで生まれる議 論, 観測されるコミュニケーションは, 従来のパーラメ ンタリーディベートとは異なったものになるだろう。そ れは，現在「件の宣言」が四極の形式を用いて行ってい るものに近づくかもしれない.コミュニケーション場の メカニズムデザインに関してわれわれが十分な知見をも つことの意味は，これらの設計変数がコミュニケーショ ンの軌跡に与える影響を事前に予測できるようになるこ とにある，たとえるならば, コミュニケーション場のメ カニズムの設計変数は観測されるコミュニケーションと いう表現型を生み出す遺伝子なのである.

これらのコミュニケーション場のメカニズムにおける 設計変数概念は本論文において新規に導入したもので あるが，現時点では決して網羅的なものではない，これ は一般的なコミュニケーション場において重要な設計変 数でありながら，その網羅性においては初期的なリス卜 
Table 1 Comparison of some design variables of the three communication mechanisms

\begin{tabular}{|c|c|c|c|c|}
\hline 設計変数 & ビブリオバトル & $\begin{array}{c}\text { パーラメンタリー } \\
\text { ディベート }\end{array}$ & 発話権取引 & 「件の宣言」 \\
\hline $\begin{array}{l}\text { 対立構造 } \\
\text { の極配置 }\end{array}$ & $\begin{array}{c}\text { 多極的 } \\
\text { (発表者の数だけ) }\end{array}$ & 二極的 & $\begin{array}{c}\text { 多極的 } \\
\text { (議論の中で動的に変わる) }\end{array}$ & $\begin{array}{l}\text { 多極的 } \\
\text { (四極) }\end{array}$ \\
\hline 決定方式 & 民主的投票 & $\begin{array}{c}\text { ジャッジによる判断 } \\
\text { (民主的投票とする } \\
\text { 場合もある) }\end{array}$ & 決定しない & 民主的投票 \\
\hline $\begin{array}{l}\text { 意見の表出 } \\
\text { への配慮 }\end{array}$ & $\begin{array}{c}\text { 「一番読みたくなっ } \\
\text { た本」に投票する } \\
\text { のみであり, } \\
\text { 発表者が評価 } \\
\text { されるわけ } \\
\text { ではない. }\end{array}$ & $\begin{array}{l}\text { 立場が乱択により } \\
\text { 決まるので, } \\
\text { 議論と人格・意見 } \\
\text { が分離される. }\end{array}$ & $\begin{array}{l}\text { 勝敗や意思決定 } \\
\text { は含まれない. }\end{array}$ & $\begin{array}{l}\text { 立場が乱択により } \\
\text { 決まるので, } \\
\text { 議論と人格・意見 } \\
\text { が分離される. }\end{array}$ \\
\hline $\begin{array}{c}\text { 発話時間 } \\
\text { の制御 }\end{array}$ & $\begin{array}{l}\text { 集中管理 } \\
\text { 固定配分 }\end{array}$ & $\begin{array}{l}\text { 集中管理 } \\
\text { 固定配分 }\end{array}$ & $\begin{array}{l}\text { 分散管理 } \\
\text { 動的配分 }\end{array}$ & $\begin{array}{c}\text { 集中管理（演説時）・ } \\
\text { 放任 } \\
\text { (グループごと議論時) }\end{array}$ \\
\hline
\end{tabular}

に過ぎない。より網羅的なコミュニケーション場のメカ ニズムの比較を通して分類学の構築をさらに推進する 必要がある。そして，その各設計変数の効果に関しては フィールド実験などを通して明らかにされていく必要が あるだろう。また，ゲノムが生命を形作るときに，遺伝 形からの一対一対応で，表現型を形作らず，そこに非線 形な効果があるように，各メカニズムのアルゴリズム表 現で示したような場の動的特性に応じてその効果を変え る可能性もある。これらに関しても，さらなる検証が必 要である.

\section{4. 関連研究分野と隣接概念}

本章ではコミュニケーション場のメカニズムデザイン と対象や視点を共有する関連研究分野と隣接概念につい て紹介する。これらの分野や概念が相互浸透しながら， 研究分野を推進していく必要がある.

\section{1 ファシリテーション技法}

コミュニケーション場を改善するアプローチとして最 も多く取られてきたのはファシリテータによるアプロー チである $[17,18]$. ファシリテータとは，会議のおける司 会のような役割であり，コミュニケーション場を円滑に したり，運営するための役割を担う人物である。ファシ リテータが行うコミュニケーション場での役割をファシ リテーションとよぶ. このファシリテーションを行うう えでのツールや技法のことがファシリテーションツール /技法とよばれる。ワークショップ運営技法などとよぶ こともある。

本論文ではコミュニケーション場のメカニズムの一種 と見なすブレインストーミングやオープンスペーステ クノロジーなどもファシリテーション技法の一種として 捉えられる $[19,20]$. しかし，ファシリテーション技法 も広範な概念であり，そのすべてがコミュニケーション 場のメカニズムとして捉えられるわけではない. Fig. 1
の階層に照らせば, ファシリテーション技法にはコミュ ニケーション場のメカニズムに関わるものと，コミュニ ケーション場, コミュニケーションの軌跡のそれぞれの 設計や制御，またはその部品に関わるものが渾然一体と して含まれている。それは，ファシリテーション技法と いうくくりそのものが，コミュニケーション場に存在す るシステムそのものではなく, あくまでファシリテータ の存在を前提としてその人物の視点によってくくられた ものだからである。

コミュニケーション場のメカニズムデザインでは，ファ シリテータという特殊な存在を必要としない状況をむし ろ良しとする。ファシリテータに依存するコミュニケー ション場のメカニズムは, 技能のあるファシリテータを もたない組織では利用不可能になってしまう。コミュニ ケーション場の改善に，ファシリテータという人材の育 成コスト，調達コストがボトルネックとなるし，結局は， 人手による制御となる。蛙に，全国に広がり，さまざ まな場所でコミュニケーション場を改善するメカニズム であるためには，ファシリテータ依存性を極限まで減ら せることが望ましい. ビブリオバトルは司会の力量にほ とんど依存せず，開催することのできるメカニズムとし て知られている。

コミュニケーション場のメカニズムとファシリテーショ ン技法は隣接した概念でありながら，ファシリテータの 存在を前提とするかしないかが大きく異なるのである. ただし，あらゆるコミュニケーション場のメカニズムが 完全にファシリテータの存在を消せるわけではない.し かし，より属人性の低いメカニズム，ファシリテータの 技量に依存せず同様の効果を得られるならば，そのよう なメカニズムの方が, 他のコミュニティ, 組織への展開 可能性の意味（つまり，スケーラビリティ）において良 いメカニズムであるという視点は重要である. 


\section{2 メカニズムデザイン}

メカニズムデザインは日本語で制度設計と訳される. 制度設計という意味においては，非常に広義であり，コ ミュニケーション場のメカニズムデザインはコミュニ ケーション場における制度設計として自然に解釈できる であろう。一方で, 学術用語としてメカニズムデザイン とよぶ場合にはゲーム理論や経済学で言うところのメカ ニズムデザインを指すことがほとんどである [21]. メカ ニズムデザイン論とは資源配分や公共的な意思決定など で実現したい目標を自律分散的に実現するルールを設計 することを目指す学問である，経済学のメカニズムデザ インでは上記の目標が何らかの関数で定義されることを 前提とすることが多く，その意味では良く定義された数 学的基礎を前提として議論されることが多い. ただし， 重要なのは中央集権体制をもつ運営者が個々人の私的情 報を正しく把握できないという不可能性から出発し, 運 営者が人々の私的情報を直接は取得できないままでいか にして，望ましい社会的帰結を導くことができるかとい う，情報分権的な制度構築を目指す色彩の強い学問であ る [21]. オークション理論やマッチングメカニズムなど が好例だろう $[22,23]$.

基本的にコミュニケーション場のメカニズムデザイン と本論文で言う場合には，その意味は，上記メカニズム デザインのアナロジー，もしくは拡張に基づいている. 会議や話し合いの場においては司会やファシリテータは 人々の私的情報を入手できない. あらゆる人々が他人の 頭の中はのぞけない情報分権的な状況にある. 多くのコ ミュニケーション場において起きる非効率や非生産的な 時間はこれに端を発している場合が多い。経済学におい てメカニズムデザインが長い歴史的研究の文脈の上で成 立してきたのと同様に，コミュニケーション場における メカニズムデザイン論を構築したいというのが, 本研究 領域における最大の野心の一つなのである.

一つのアプローチはメカニズムデザイン論を拡張する ことで，コミュニケーション場のメカニズムデザインの 基礎的枠組を供給することであろう。拈もに選考順序な どを扱う経済学におけるメカニズムデザイン論に対して, コミュニケーション場のメカニズムデザイン論において は，発話内容や意見の論理的関係を扱う必要すらあるだ ろう。そのような視点からコミュニケーション場のメカ ニズムデザイン論を構築するような研究はまだ存在せず, 未踏領域としての学術研究が期待される.

\section{3 マルチェージェントシステム}

システム工学や最適化, 制御工学, 複雑系など幅広い 分野でマルチエージェントシステムについて議論されて きた。端的にいえば，マルチエージェントシステムとは 複数の主体がそれぞれに分散的に意思決定することで， 作動するシステムである。それが対象とされ制御や最適 化がなされる研究や，マルチエージェントシステムその
ものをシミュレーションすることで社会現象の理解や予 測をしようという研究などがある $[24,25]$.

一方で，コミュニケーション場そのものは不可避にマ ルチエージェントシステムである。コミュニケーション 場に存在する各参加者は自律的な主体であり, それぞ れがそれぞれの意思決定に基づき，発言したり，投票し たりする。そのようにシステム論的な意味で，コミュニ ケーション場を自律分散的なマルチエージェントシステ ムとして捉えることは，コミュニケーション場のメカニ ズムデザイン研究において何よりも重要である.

一方で，コミュニケーション場そのものがマルチエー ジェントシステムとして数理的モデル化されてきたわけ でも，シミュレーション研究されてきたわけでもない. その理由としては，コミュニケーション場における多様 な言語的コミュニケーションのモデル化をどうすべきで あるかという点に関して，困難があったのも一因だろう. しかし，だからといって，コミュニケーション場マルチ エージェントシステムが, モデル化できないと決まった わけではない。 あるコミュニケーション場のメカニズム をマルチエージェントシステムとしてモデル化し分析す る研究や，マルチエージェントシステムでモデル化する ことでコミュニケーション場のメカニズムの設計に示唆 を与える研究など，幅広い研究が期待される.

\section{4 集合知}

集合知 (Collective Intelligence) とは多くの人々に分 散した「知」を集約することにより得られる「知」のこ とを指す。群衆の英知 (Wisdom of Crowds) とよばれ ることもある $[26]$. たとえば，西垣は「人々のいわゆる 『衆知』，とくにインターネットを利用して見ず知らず の他人同士が知恵を出し合って構築する知のことを意味 する.」という定義を与えている [27]. 集合知というと Wikipedia $^{1}$ のようなインターネット上で集められる知 識のことなど，極めて広範な物事を指すことになるが， コミュニケーション場のメカニズムデザインの視点から 重要となるのは集合知メカニズムである.

ある場（インターネット上の空間でもよい）に人々が 集まったからといって，集合知が生まれるわけではな い [28]. そこには，何らかの集合知メカニズムが必要で ある。たとえば，予測市場は予測のための証券を発行し， 市場の力を使って集合知としての予測を生む優れた集合 知メカニズムである $[28]$. たとえば，簡単な集合知メカ ニズムの例として多数決が挙げられる。多数決のような 単純な集合知メカニズムであっても，適切に用いれば非

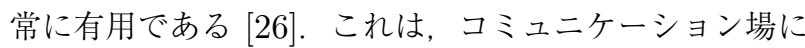
おいて人が集まりさえすれば，集合知が生まれるわけで はないことと同根である。会議に人だけ集めても，司会 進行が悪かったり，何のメカニズムも準備せずに放り出 せば，ゴールのない無為な時間が過ぎるだけである。実

\footnotetext{
${ }^{1}$ https://en.wikipedia.org/
} 
際に，そのような無意識な悪行によって，多くの組織が むだな会議をもつことで生産性を低下させていたり，多 くの社会において衆愚とよばれる状況が生じている。こ の意味で，集合知メカニズムとコミュニケーション場の メカニズムは多くの部分を共有する.

しかし，集合知メカニズムの議論では，得られる「知」, とくに形式知に焦点を当てる場合が多い.つまり, Fig. 2 に扮ける $Y$ である。，一方で，既存の多くのコミュニケー ション場のメカニズムにおいては，知識の共有であった り，各参加者の気づき，スキルの向上といった，参加者 自身の状態変化をその効果の重要な部分として捉えてい るものが多い. Fig. 2 における $\left\{X_{j}^{\prime}\right\},\left\{K_{j}^{\prime}\right\},\left\{S_{j}^{\prime}\right\}$ である. 実際の組織や社会の話し合いが，その結論のみに重きを 置くことはむしろまれである。その意味においては，コ ミュニケーション場のメカニズムが扱う, 対象は集合知 メカニズムが主として扱ってきた範囲よりも大きいとも いえる.

\section{5 ゲーミフィケーション}

ゲームには人を夢中にさせる力がある。マクゴニガル はチクセントミハイのフロー体験という概念を用いて説

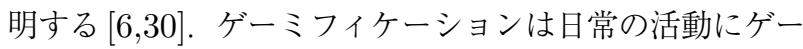
ム要素を加えることで，ゲームの人を動機づける機能を 援用して, 参加者の能動的な参画を引き出そうというも のである [31]. たとえばビブリオバトルは書評のゲーミ フィケーションとして捉えられる [9]. マクゴニガルは ゲームの四要素としてゴール，ルール，フィードバック， 自発的な参加を挙げている $[6]$. その視点からいえば, コ ミュニケーション場のメカニズムデザインとは，しばし ば,コミュニケーション場のゲーミフィケーションとし ても捉えられる.

コミュニケーション場においては各参加者の出すべき 情報が脳内の私的情報であるという特性上から，各主体 の自発的な参加を引き出すことが重要になる。理屈上, 各参加者が積極的に参加すれば有用な効果が得られる メカニズムを設計したとしても，各参加者の積極的な参 加が引き出せなければ，そのコミュニケーション場のメ カニズムは無用の長物となるだろう。実世界に扔いてコ ミュニケーション場のメカニズムが有用であるためには, 各参加者の動機システムに適切に作用し, 各参加者の貢 献を引き出すゲーミフィケーションが必要である。また， より包括的な概念として，ゲーミング\&シミュレーショ ンという概念があるが，コミュニケーション場のメカニ ズムデザインを同様の意味で含む概念として捉えられる であろう。

\section{6 コミュニケーション支援のための情報通信 技術と人工知能技術 \\ ヒューマンインタフェースや人工知能の分野に扔いて,} さまざまな形で，コミュニケーション場を支援するため の技術が研究開発されてきた。たとえば，会議参加者の

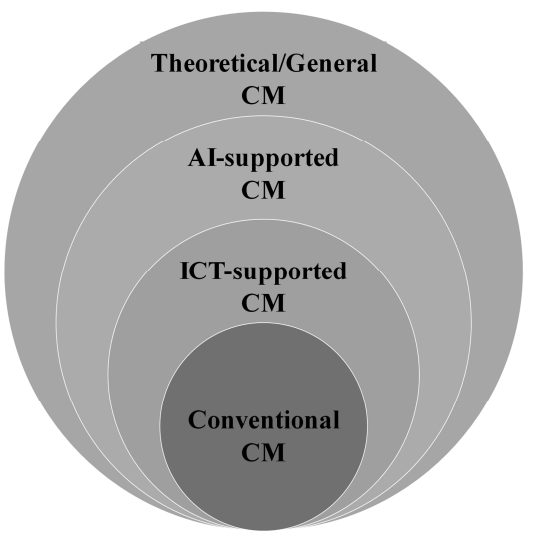

Fig. 4 Relationship between general, conventional, and ICT/AI-supported communication-field mechanisms

発言量や行動を計測し，フィードバックすることで，会 議の改善に役立てようというものなどである $[32,33]$. し かし，会議や話し合い全体を俯㒈するシステム論的な視 点での研究は少なく, ヒューリスティックな手当に留まっ てきた感は否めない

コミュニケーション場のシステム全体を俯瞰するコ ミュニケーション場のメカニズムデザインの視点に立つ ことで，コミュニケーション場の支援に関する情報技術 開発に関しても，その位置付けをより明確にできると考 える. Fig. 4 に示すように，コミュニケーション場のメ カニズムには概念的な段階を考えることができる。ま ず, 現在, 存在しているコミュニケーション場のメカニ ズム (Conventional communication-field mechanism) である。これに対して,メカニズムの設計変数に関す る議論に基づいて，もしくは，発見的にわれわれはさ まざまなメカニズムを考えることができる，その理屈 上存在しうるコミュニケーション場のメカニズムを理 論上のコミュニケーション場のメカニズム (Theoretical communication-field mechanism) として一番外側にと る。しかし，その圧倒的多数は技術的理由により実現で きない，たとえば，発話権取引はその原著論文におい て紙のカードを使って発話権のやり取りを実現してい た。しかし，これでは，10人以上のような多くの人間 が参加して発話権取引を実現することは，現実的には 煩雑になり難しい。しかし，これは発話権を管理するモ バイルアプリケーションを開発することで実現可能にな る、たとえば，会議における詭弁を抑制するために，詭 弁を話した分だけ減点が与えられるメカニズムを考元 たとする。これも現状では実現が難しいが, 音声認識 と詭弁検知の自然言語処理技術により実現できる可能 性がある。これは情報通信技術や人工知能技術がコミュ ニケーション場のメカニズムの進化に貢献することを 意味している (ICT/AI-supported communication-field mechanism). 伊藤らは人工知能技術を活用しながら大 
規模合意形成支援システムの創成を目指している [34]. 一方で, 逆に人工知能研究の進化がコミュニケーショ ン場のメカニズムにより加速される可能性もある。一般 的に，何の制約もないコミュニケーション場において生 じる会話や発話を音声認識したり言語処理するのは容易 ではない.しかし，コミュニケーション場のメカニズム はコミュニケーション場に制約を与えることにより，観 測されるコミュニケーションに一定の制約を与える。こ の制約により人工知能技術の適用が適用可能，もしくは， 開発可能になる可能性がある。これにより，段階的にコ ミュニケーション場において活用可能な音声認識技術, 自然言語処理技術が開発できれば，コミュニケーション 場のメカニズムデザインが, 人工知能技術の進化に寄与 することが考えられる。 コミュニーション場のメカニ ズムデザインと人工知能研究の共進化を見込むことがで きるのである。

\section{5. おわりに}

本論文では対話や議論を通して，人々の中に分散した 知識や情報を統合し，組織やコミュニティにおいて集合 知を生み出し, また，意思決定を行っていくためのコミュ ニケーション場を改善していくための学問的枠組みとし てのコミュニケーション場のメカニズムデザインに関し て，システム論的な視座からその概念構築を行った。 た，先行事例を紹介し，その対比を通して設計変数を抽 出し, 設計原理を探求するという目標について述べた. さらに関連研究領域との関係性を議論した。

人間のコミュニケーションに関する研究は幅広いし， 実践や実世界での取り組みはより幅広い。その改善をシ ステム工学的になすことが可能であれば，その成果の 影響範囲は大変大きなものとなるだろう。コミュニケー ション場の研究の難しさは，その一回性や，捉えがたい 多様性や動的特性，また，言語的コミュニケーションの 意味内容の数理モデルとしての扱いにくさなどにある. そこに解くべき問題がなかったわけではなく，眼前に問 題はあったのに，われわれの学問的道具立てが未成熟で あったからシステム論的視点から取り組めてこなかった のである.コミュニケーション場を研究するためには， その対象システムが社会的に結合されたマルチエージェ ントシステムとしての自律的作動であることを前提とし た制御・設計を論じる必要がある。本論文ではこのよう な場の制御問題をシステム論的に捉えることで，コミュ ニケーション場のメカニズムデザインという研究アプ ローチの位置付けを示した

本論文で導入したコミュニケーション場のメカニズム デザインはコミュニケーション場に対してシステム論的 な見方を与えて，学術研究の概念枠組みを与えるもので ある．新たな体系を構築しつつ現場の問題を解決してい くためには，先に述べたような関連研究分野の研究者と 学際的な協調を図りながら, 分析的研究と実践的研究を
幅広く推進していく必要がある。

\section{謝辞}

本研究は (一部), JST未来社会創造事業 JPMJMI17C7 の支援を受けたものである。

\section{参 考文 献}

[1] 野中, 竹内: 知識創造企業, 東洋経済新報社 (1996)

[2] 谷口: コミュニケーションするロボットは創れるか一 記号創発システムへの構成論的アプローチ, NTT 出版 (2010)

[3] T. Taniguchi, T. Nagai, T. Nakamura, N. Iwahashi, T. Ogata and H. Asoh: Symbol emergence in robotics: a survey; Advanced Robotics, Vol. 30, Nos. 11-12, pp. 706-728 (2016)

[4] 谷口, 須藤: コミュニケーションのメカニズムデザイン: ビブリオバトルと発話権取引を事例として; システム/ 制御/情報, Vol. 55, No. 8, pp. 339-344 (2011)

[5] 川上: 不便益: 手間をかけるシステムのデザイン, 近代 科学社 (2017)

[6] マクゴニガル: 幸せな未来は「ゲーム」が創る, 早川書 房 (2011)

[7] 谷口, 川上, 片井: ビブリオバトル：書評により媒介され る社会的相互作用場の設計; ヒューマンインタフェース 学会論文誌 $(2010)$

[8] 奥, 赤池, 谷口: ビブリオバトルにおける発表制限時間 のデザイン; 日本経営工学会論文誌, Vol. 15, No. 1, pp. 95-106 (2013)

[9] 谷口: ビブリオバトル 本を知り人を知る書評ゲーム, 文藝春秋 $(2013)$

[10] 中川: 授業でできる即興型英語ディベート，ネリーズ出 版 $(2017)$

[11] 茂木: ザ・ディベート一自己責任時代の思考・表現技術, ちくま新書 $(2001)$

[12] 亀田: 合議の知を求めて グループの意思決定, 共立出 版 (1997)

[13] 古賀, 谷口: 発話権取引：話し合いの場における時間配 分のメカニズムデザイン; 日本経営工学会論文誌, Vol. 65, No. 3, pp. 144-156 (2014)

[14] 石川, 谷口: 発話権取引を用いた web 会議システムの開 発; 第5 58 回システム制御情報学会研究発表講演会 $(2014)$

[15] 蓮行, 末長, 紙本, 黒木, 田中: コミュニケーション場の メカニズムとしての件の宣言; 計測自動制御学会システ ム・情報部門学術講演会 2018 (2018)

[16] 末長, 蓮行, 紙本, 黒木, 田中: 演劇ワークショップ型ディ ベートにおける多極性の影響分析一件の宣言を事例と して; 計測自動制御学会システム・情報部門学術講演会 2018 (2018)

[17] 三上: 地球規模での市民参加におけるファシリテーター の役割：地球温暖化に関する世界市民会議 (wwviews) を事例として; 科学技術コミュニケーション=Japanese Journal of Science Communication, Vol. 7, pp. 19-32 (2010)

[18] 池田: 組織におけるファシリテーションに関する探索的 
研究: メンバーの自律および協動はいかにして「促進」 されるか; 日本コミュニケーション研究, Vol. 44, No. 1, pp. 85-106 (2015)

[19] D. Gray, S. Brown and J. Macanufo: ゲームストーミ ング 会議, チーム, プロジェクトを成功へと導く 87 のゲーム, オライリージャパン (2011)

[20] オーエン: オープン・スペース・テクノロジー : 5 人から 1000 人が輪になって考えるファシリテーション, ヒュー マンバリュー (2007)

[21] 坂井, 藤中, 若山：メカニズムデザイン：資源配分制度の 設計とインセンティブ，ミネルヴァ書房 (2008)

[22] H. Landemore and J. Elster: Collective Wisdom: Principles and Mechanisms, Cambridge University Press (2012)

[23] 横尾: オークション理論の基礎, 東京電機大学出版局 (2006)

[24] Y. Shoham and K. Leyton-Brown: Multiagent Systems: Algorithmic, Game-theoretic, and Logical Foundations, Cambridge University Press (2008)

[25] 村田, 鵜飼: 政策グリッドコンピューティングとマルチ エージェントシミュレーション, 多賀出版 (2008)

[26] スロウイッキー：「みんなの意見」は案外正しい， KADOKAWA (2009)

[27] 西垣: 集合知とは何か：ネット時代の「知」のゆくえ, 中 央公論新社 $(2013)$

[28] 水山: 集合知メカニズムとそのビジネスへの応用; 人工 知能, Vol. 30, No. 4, pp. 417-422 (2015)

[29] 水山, 鎌田: 予測市場システムに基づく衆知集約型需要 予測法の研究; 日本経営工学会論文誌, Vol. 59, No. 4, pp. 330-341 (2008)

[30] チクセントミハイ: フロー体験入門一楽しみと創造の心 理学 (2010)

[31] 井上: ゲーミフィケーション: ゲームがビジネスを変え
る, NHK 出版 (2012)

[32] T. Kim, A. Chang, L. Holland and A. S. Pentland: Meeting mediator: enhancing group collaboration using sociometric feedback; Proceedings of the 2008 ACM Conference on Computer Supported Cooperative Work, pp. 457-466, ACM (2008)

[33] O. Kulyk, J. Wang and J. Terken: Realtime feedback on nonverbal behaviour to enhance social dynamics in small group meetings; International Workshop on Machine Learning for Multimodal Interaction, pp. 150-161, Springer (2005)

[34] 伊藤：エージェント技術に基づく大規模合意形成支援シ ステムの創成, 経営システム (2018)

\section{著者略歴}

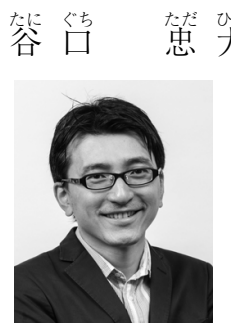

(正会員)

1978 年 6 月 24 日生. 2006 年京都大学大 学院工学研究科博士課程修了. 2005 年日 本学術振興会特別研究員 (DC2), 2006 年 同 (PD), 2007 年京都大学情報学研究科に て同 (PD), 2008 年立命館大学情報理工学 部助教, 2010 年同准教授, 2017 年同教授 となり現在に至る。 2015 年から 2016 年までインペリアル . カレッジ・ロンドン客員准教授，また，2017 年より株式会 社パナソニックの客員総括主幹技師を務める。創発システム 論を基軸としながら，人工知能，記号創発ロボティクス，コ ミュニケーション場のメカニズムデザインに関する研究に従 事. システム制御情報学会奨励賞, 論文賞, 砂原賞など各種 学会賞等を受賞. IEEE，人工知能学会などの会員 